\title{
Pharmaceutical Market Structure in India \& Competition Concerns
}

\section{OPEN ACCESS}

Manuscript ID:

ASH-2020-08013295

Volume: 8

Issue: 1

Month: July

Year: 2020

P-ISSN: 2321-788X

E-ISSN: 2582-0397

Received: 15.05.2020

Accepted: 25.06.2020

Published: 02.07.2020

Citation:

Chitra, M., and Nandan

Kumar. "Pharmaceutical

Market Structure in India

\& Competition Concerns."

Shanlax International

Journal of Arts, Science and Humanities, vol. 8, no. 1, 2020, pp. 233-241.

DOI:

https://doi.org/10.34293/

sijash.v8i1.3295

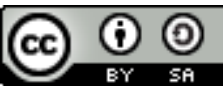

This work is licensed under a Creative Commons Attribution-ShareAlike 4.0 International License

\section{Chitra}

Assistant Professor, Department of Econometrics

Madurai Kamaraj University, Madurai, Tamil Nadu, India

D https://orcid.org/0000-0002-6427-0988

\section{Nandan Kumar}

Joint Director (Economics), Competition Commission of India, New Delhi, India

\section{Abstract}

Health Status of any country depends upon its preventive, curative, and promotive measures. But to implement these measures with available skilled human resources, and infrastructure, the growth of the pharmaceutical market is an essential one. Health Status is a function of health professionals, health infrastructure, invention, and innovations in the health sector, and the nature of government programs and policies. The Government of India exposed 'Pharma Vision 2020' aimed at making India a global leader in end-to-end drug production. Permission time for new facilities has been reduced to boost investments. Further, the government introduced devices such as the Drug Price Control Order and the National Pharmaceutical Pricing Authority to deal with the issue of affordability and availability of medicines (www.idma.com). India's cost of making is significantly lower than that of the US and almost half of that of Europe. It gives a competing edge to India over others. (Sectoral Report / Sep 2016). The competition in these markets is very crucial for making quality drugs at affordable prices to consumers. Competition law plays an essential role in dealing with anti-competitive issues in the sector and maintains competitive markets. Hence the researcher attempted to view the status of existing Indian pharmaceutical market structure, government regulations, an,d common anti-competitive concerns in the sector. Too much regulation reduces competition in the market. An equal act of management and maintaining competition is required to benefit human society in reducing theirs out of pocket expenditure for pharmaceutical products. Keywords: Pharma Vision 2020, Consumers, Pharmaceuticals, Drugs and Public Sector

\section{Introduction}

Pharmaceutical products play an influential role in healthcare, along with well-trained and motivated health professionals. The pharmaceutical sector makes a valuable contribution to improving public health by developing, producing, distributing, and marketing the needed drugs or pharmaceutical products. Several characteristics of the pharmaceutical industry and the overall healthcare sector have suggestions for the level of competition in these markets. Some of the issues like a conspiracy between players at different levels in the pharmaceutical supply chain, exclusive supply, and coercive distribution agreements, patent-related issues, anti-competitive mergers, etc. adversely affect competition in the market. Due to monopoly conferred by patents, originator drug companies enjoy substantial market power and may abuse it in various ways to extend the continuation of its patented products for as long as possible.

India is one of the most important beginning markets of pharmaceuticals, and the competition in these markets is very crucial for making quality drugs at affordable prices to consumers. Regulatory interventions to the pharmaceutical industry through competition laws play an essential role in dealing with the anticompetitive issues in the sector and maintain competitive markets. 


\section{Characteristics of Pharmaceutical Market Structure}

Characteristics of the pharmaceutical market in India are the same as that of the market at a global level, except that there may be additional complicating factors:

Information Asymmetry: Pharmaceutical products are technologically complex products to understand. They may have an inherent high but unobservable risk to human lives. This implies that there are serious issues of information asymmetry running through the entire supply chain of pharmaceutical distribution and consumption. The information gap may exist among the producer of medicine, distributor, doctors, chemist, and consumers. More often, producers of medicine may promote medicines with a better price margin with the medical community. Consumer's lack of awareness about generic drugs and hence the available ability of the substitutes, i.e., cheap generic drugs vis-à- vis the costly branded medicines is another information asymmetry issue. This information asymmetry at times may result in forcing out the generic producers out of the market and creating an artificial demand for branded medicines.

Consumers are not Decision-Makers: Except for the over the counter medicines which are available without a prescription by a doctor, the decision regarding the consumption of drugs/pharmaceuticals is not taken by the consumers. The users of pharmaceutical products neither know about the drugs, nor do they have the choice of buying them on their own. This leaves the consumers at the mercy of the healthcare providers. The choice of medicine as well its brand is generally determined by the physicians, who may have a particular interest in prescribing one brand of medicine over the other, rather than be guided by the prices. Even the chemists do not have the legal authority to change the branded medicine prescribed by the doctor with that of a generic one.

Consumers are Price Takers: Demand for the pharmaceutical products is derived demand, not a direct demand like other necessary goods. On behalf of the patient, the doctor is prescribing the drugs for their sickness, whether acute or chronic. The advice of the doctor forced to buy pharmaceutical products for the price without bargaining. The price is fixed by the supplier based on the guidelines prescribed by appropriate authorities. Patients who called as a consumer have no role in price, and he/she is a price taker. Consumers are neither aware of the meaning of Rx symbol, a drug with a prescription, and drug without prescription (OTC- Over the Counter drugs), nor are they in a position to check all these pricing irregularities given their health conditions during sickness. Hence all consumers are cent percent price takers not makers in this kind of market.

Relatively Inelastic Demand: Demand for pharmaceutical products is relatively inelastic demand (low price elasticity). This is because their consumption is not directly dependent on price, rather it is compulsion.

Lack of Countervailing Power: In India, most of the expenses on drugs are born by the individuals themselves, known as out-of-pocket expenses (OOP). Public expenditure as a percentage of total health expenditure in India was just 32.2 percent in 2013, and out of pocket healthcare expenditure as a percentage of total private expenditure on health in India was 85.9 percent in $2013^{1}$ (one of the highest in the world). Further, India has very low coverage under health insurance. ${ }^{2}$ Absence of institutions like government, hospitals, etc., who can effectively bargain with drug producers, reduce countervailing power on demand side of the Indian market.

\section{Indian Pharmaceutical Industry}

The Indian pharmaceutical Industry is estimated to grow at $20 \%$ compound Annual growth rate (CAGR) over the next five years. ${ }^{3}$ The entries of generic drugs in the market are the major $r$ reason for the drastic fall in prices of medicines. They have played an important role in improving the accessibility of medicines in India. The Indian pharmaceutical industry is a major contributor to the

1 As per data available on World Bank website.

2 As per 2013-14 Annual Report of the Insurance Regulatory and Development Authority of India; only 17 percent of the population is covered under any form of insurance scheme.

3 Indian Pharmaceutical Industry, http://www.ibef.org/ industry/pharmaceutical-india.aspx 
requirement for pharmaceutical products globally and is a cheap source of medicines to the developing world. The Indian pharmaceutical industry accounts for approximately $10 \%$ of the world's pharmaceutical production by volume and $1.4 \%$ in terms of the value of production. ${ }^{4}$ India ranks 4 th in terms of volume of production and 13th in terms of the value of Producation ${ }^{5}$. The pharmaceutical products also constitute a significant share of India's total exports the year 2011-12, pharmaceutical products constituted 4.3 percent of the total exports from India. ${ }^{6}$ Currently, $100 \%$ FDI through automatic route for green field the investment and the Government approval route for brownfield investment is allowed in the sector. Further, in brownfield investment, the 'non-compete' clause is not allowed except in special circumstances with the approval of the Foreign Investment Promotion Board (FIPB) ${ }^{7}$. The pharmaceutical industry is the fifth-largest foreign investment recipient in India and accounted for $5 \%$ of the total FDI equity inflows into the country during the period April 2000 to February 2014. During this period, the cumulative value of FDI equity inflows in the sector has been of the order of US\$ 11.6 billion $^{8}$.

\section{Type of Products}

Indian Pharmaceutical Companies produce 'Bulk drugs' as well as 'Formulations.' Medicines 4 Pharmaceuticals, IBEF, http://www.ibef.org/ download/Pharmaceuticals-March-2015.pdf

5 Drugs \& Pharmaceuticals, CII.

6 In the year 2011-12, pharmaceutical products constituted 4.3 percent of the total exports from India.

7 Dept. of Pharmaceuticals, Annual Report (2013-14).

8 Pharmaceuticals, IBEF, http://www.ibef.org/ download/Pharmaceuticals-March-2015.pdf sold in the market in the form of tablets, capsules, syrups, drops, intravenous fluids are 'formulations.' In contrast, the chemical molecule, which is the substance of medicine, is known as 'bulk drug' (Active Pharmaceutical Ingredients-API). Around 77 percent of the firms in the sector are engaged in the generation of formulations and only 23 percent in bulk drugs ${ }^{9}$. Indian API manufacturing segment may be classified into three categories; a) Innovative or Patented drugs under a brand name, b) Generic drugs under a brand name and, c) Generic drugs without a brand name (Generic-generic)

\section{Market Concentration}

The Indian pharmaceutical industry broadly functions under a three-tier structure. The large MNCs operating as originator drug organizations and generic groups, along with the large Indian generic organizations, form the first tier. In the second tier, the medium and small music enterprises are engaged in the production of marked generics and contract production-related activities. In the third tier, most of the units in the small scale sector are interested in the production of generic-generic medicines. In 2014, the top four firms in the sector estimated for a 20 percent market share in terms of revenue. In contrast, top 10 firms garnered 39 percent market share ${ }^{10}$. Going by several firms alone, the Indian pharmaceutical Industry is dominated by small scale firms. The production of pharmaceuticals in India is concentrated in Maharashtra, Gujarat, West Bengal, Andhra Pradesh, and Tamil Nadu.

9 www.dsir.gov.in/reports/isr1/Pharmaceuticals/7_3.pdf 10 Pharmaceuticals, IBEF, http://www.ibef.org/ download/Pharmaceuticals-March-2015.pdf

Table 1: Trend of Pharmaceutical Products in India

\begin{tabular}{|c|c|c|c|c|}
\hline $\begin{array}{c}\text { Value of Production (Including Exports) } \\
\text { of Bulk Drugs and Formulations }\end{array}$ & $\begin{array}{c}\text { Bulk Drugs } \\
\text { Rs in crores }\end{array}$ & $\begin{array}{c}\text { Growth } \\
(\%)\end{array}$ & $\begin{array}{c}\text { Formulations } \\
\text { Rs in crores }\end{array}$ & $\begin{array}{c}\text { Growth } \\
\text { (\%) }\end{array}$ \\
\hline $2001-02$ & 5439 & 19.7 & 21104 & 15 \\
\hline $2002-03$ & 6529 & 19.3 & 24185 & 14.8 \\
\hline $2003-04$ & 7779 & 19.14 & 27692 & 14.5 \\
\hline $2004-05$ & 9249 & 18.9 & 31685 & 14.4 \\
\hline $2005-06$ & 10635 & 15 & 38022 & 20 \\
\hline $2006-07$ & 12125 & 14 & 45626 & 20 \\
\hline $2007-08$ & 13822 & 14 & 54751 & 20 \\
\hline
\end{tabular}




\begin{tabular}{|c|c|c|c|c|}
\hline $2008-09$ & 15204 & 10 & 66796 & 22 \\
\hline $2009-10$ & 17487 & 15 & 83495 & 25 \\
\hline $2010-11$ & 17894 & 15.2 & 98691 & 18.1 \\
\hline $2011-12$ & 20936 & 17 & 112014 & 13.5 \\
\hline
\end{tabular}

The Indian pharmaceuticals market increased at a CAGR of 17.46 percent in 2015 from US\$ 6 billion in 2005 and is demanded to develop at a CAGR of 15.92 percent to US\$ 55 billion by 2020 . Table -1 reveals the value of production's growth of pharmaceutical products of both kinds. The actual data of the value of production gives an increasing trend in value over the years. But the point of growth in percentage figures is the zig-zag trend over the years. The decreasing percentage of growth in value of production of Bulk drugs during 2004-2010, meanwhile, an increasing percentage of growth in value of production of formulation for the same periods. The changes may be subject to the demand or sale of products or may be an inventory of the products. The sum of the total value of production and their growth at a particular point of time is constant over the periods as 35 percentages except 2009-10. The other years, the summing of both growth rates reveals 34-35 percentages and gives a picture of the constant growth of the pharmaceutical products in its value of production for India. Hence the supply of Pharmaceuticals products is constant over the periods.

Table 2: Status of International Trade in India

\begin{tabular}{|l|c|c|}
\hline \multicolumn{1}{|c|}{ Year } & $\begin{array}{c}\text { Exports of } \\
\text { Medicines \& } \\
\text { Pharmaceuticals } \\
\text { Products } \\
\text { (Rupees in Crore) }\end{array}$ & $\begin{array}{c}\text { Import of } \\
\text { Medicines \& } \\
\text { Pharmaceuticals } \\
\text { Products } \\
\text { (Rupees in Crore) }\end{array}$ \\
\hline $2012-13$ & 79840 & 32691.98 \\
\hline $2013-14$ & 90341 & 31077.95 \\
\hline $2014-15$ & 94275 & 32214.27 \\
\hline $\begin{array}{l}\text { 2015-16 } \\
\text { (upto Dec) }\end{array}$ & --- & 24926.01 \\
\hline
\end{tabular}

Source: Annual Report 2015-16, Department of Pharmaceutical, Import figures in USD converted to INR.

The table 2 shows the export and import value of pharmaceutical products. The export value is interested in checking the difference between export and import, it I .s clear that there exists an absolute and relative inequality that favors the India in value of trade in the pharmaceutical sector. India is enjoying the benefit of international trade in the pharmaceutical market. Indian drugs are transported to more than 200 countries in the world, with the US as the key market. Generic drugs account for 20 percent of global exportation in terms of volume, making the country the biggest provider of generic medicines globally and expected to expand even further in the coming years. Pharmaceuticals Exports Promotion Council(Pharmexcil) expects pharmaceutical exports to reach US\$ 25 billion in 2015. The Government of India plans to set up a US\$ 640 million venture capital fund to boost drug discovery and strengthen pharmaceutical infrastructure. The 'Pharma Vision 2020' by the government's Department of Pharmaceuticals aims to make India a major hub for end-to-end drug discovery. India has also directed its lead over China in pharmaceutical exports with a year-on-year extension of 11.44 percent to US\$ 12.91 billion in FY 2015-16, according to data from the Ministry of Commerce and Industry. Imports of pharmaceutical commodities rose marginally by 0.80 percent year-on-year to US $\$ 1,641.15$ million. Overall, drug permissions given by the US Food and Drug Administration (USFDA) to Indian corporations have nearly doubled to 201 in FY 2015-16 from 109 in FY 2014-15. The country considers for around 30 percent (by volume) and about 10 percent (value) in the US\$ 70-80 billion US generics market. The market size of the Indian pharma industry, which is expected to grow over 15 percent per annum between 2015 and 2020, will beat the global pharma manufacturing, which is set to grow at an annual rate of 5 percent between the same periods. The market is foreseen to grow to US\$ 55 billion by 2020 , thereby emerging as the sixth-largest pharmaceutical business globally by absolute size, as stated by Mr. Arun Singh, Indian Ambassador to the US. Branded generics subject the pharmaceuticals market, developing nearly 80 percent of the market share (in terms of revenues). 


Table 3: Status of Five Public Sector Pharmaceutical Industry in India Rupees in Crore
\begin{tabular}{|c|c|c|c|c|c|c|c|c|}
\hline \multirow{2}{*}{ CPSEs } & \multicolumn{2}{|c|}{$\mathbf{2 0 1 2 - 1 3}$} & \multicolumn{2}{|c|}{$\mathbf{2 0 1 3 - 1 4}$} & \multicolumn{2}{|c|}{$\mathbf{2 0 1 4 - 1 5}$} & \multicolumn{2}{c|}{$\begin{array}{c}\mathbf{2 0 1 5 - 1 6} \\
\text { (Upto December, 2015) }\end{array}$} \\
\hline & Production & Sale & Production & Sale & Production & Sale & Production & Sale \\
\hline KAPL & 247.39 & 214.21 & 275.73 & 241.59 & 281.81 & 247.24 & 247.40 & 228.05 \\
\hline RDPL & 86.22 & 85.67 & 54.93 & 43.50 & 25.04 & 24.90 & 21.03 & 22.88 \\
\hline HAL & 48,73 & 52.09 & 27.37 & 30.11 & 17.28 & 18.54 & 8.38 & 7.87 \\
\hline BCPL & 36.32 & 27.37 & 1.97 & 16.87 & 64.10 & 45.84 & 68.32 & 65.36 \\
\hline IDPL & 58.71 & 59.47 & 62.87 & 60.18 & 71.50 & 61.56 & 58.41 & 57.2 \\
\hline Total* & 428.64 & 438.81 & 422.87 & 392.25 & 459.73 & 398.08 & 403.54 & 381.36 \\
\hline
\end{tabular}

Source: Annual Report 2015-16, Department of Pharmaceuticals; * manipulated by the researcher

The table 3 is depicting public sector contribution in the pharmaceutical market. There are five Industries in the hands of Government situated in various regions of India. The value of production and sales of the public sector is in the above table, indicating a positive trend over the period in each industry. The public sector contribution to the pharmaceutical market is a signatory one for India's leading status in the global market.

\section{Regulatory Framework}

Given the impact on public health and the issue of safety of human lives, the world over the pharmaceutical sector is highly regulated sector, and India is no exception to it. The Indian pharmaceutical industry is regulated at two levels; licensing and pricing. The Drugs and Cosmetics Act, 1940 (Drugs Act), and the Drugs and Cosmetic Rules, 1945(Drugs Rules) regulate the manufacture, licensing, testing, distribution, import, and sale of drugs in India. The Central Drugs Standard Control Organization (CDSCO) is the Central Drug Authority to enforce the Acts above across India. The price of drugs in India is regulated by the Drug Prices Control Order (DPCO) issued under the Essential Commodities Act, 1955. DPCO has been in place since the 1970s and has been revised periodically. National Pharmaceutical Pricing Authority (NPPA) was established under the provisions of DPCO, 1995. It has the mandate to fix or revise the prices of controlled bulk drugs and formulations in the country. The NPPA also monitors the prices of nonscheduled drugs, including patented drugs. National Pharmaceutical Pricing Policy, 2012 (NPPP) and the Drug Price Control Order 2013, were issued by the Government with the objective of publishing principles for pricing of the essential drugs as laid down in the National List of Essential Medicines, 2011 (NLEM).

Table 4: Action Taken to Regulate End Consumer Price

\begin{tabular}{|c|c|c|c|}
\hline Year & No. of Samples Collected & Prima Facie Violations detected & Referred for Overcharging \\
\hline $2007-08$ & 1450 & 840 & 456 \\
\hline $2008-09$ & 520 & 284 & 172 \\
\hline $2009-10$ & 464 & 246 & 208 \\
\hline $2010-11$ & 553 & 225 & 152 \\
\hline $2011-12$ & 559 & 156 & 163 \\
\hline $2012-13$ & 626 & 165 & 389 \\
\hline $2013-14$ & 993 & 389 & 924 \\
\hline $2014-15$ & $3898 \#$ & 924 & 382 \\
\hline $2015-16^{*}$ & $2104 \#$ & 382 & \\
\hline 87 cas & 310.15 & & \\
\hline
\end{tabular}

*87 cases under process on 31.10 .2015

\#Cases of Overcharging referred from State Drug Controllers have included under the Column 'Samples Collected.' 
The table 4 explains the action taken to control the distribution price for the end-user. The drug controlling authority collected the samples in every year and trying to mitigate the overcharging. The behavior of violation and overcharging is not able to eradicate by the authorities but made is under control. The year 2014-15 shows a higher number of violations and overcharging detected by the controlling board, and the collected samples are too high when compared with previous years. It tells indirectly that if the samples are increasing, then there might be an increasing number of detection in violation of rules and regulations.

\section{Benefits of Competition and Enforcement}

Competition ensures the efficient functioning of markets and benefits consumers both directly through lower prices, enhanced quality drugs, and indirectly through its impact on economic development. Specifically, the competition allows the following:

\section{The Entry of New Players}

Competition reduces entry barriers in pharmaceutical markets and allows new entrants into the market, which improves drug availability in the markets and hence the choice of drugs. However, consumer choice is limited by the Doctor's prescription.

\section{Innovation}

The presence of several competitors force companies to invest more in research and development $(R \& D)$, which results in better quality drugs and the development of new drugs. Such drugs improve the quality of life of consumers.

\section{Quality Drugs at Best Prices}

Competition keeps prices and costs of drugs/ pharmaceuticals down. A competitive market provides consumers access to good quality medicines at comparatively lower prices.

Competition law deals with anti-competitive practices viz., cartels, abuse of dominance, anticompetitive mergers and acquisitions, which may cause consumers to harm inter-alia in the form of higher prices, lower quality, limited choice and lack of innovative products. The relevant legislation for enforcing trial in India is the Competition Act, 2002 (Act) under which the Competition Commission of India (CCI) has been installed for promoting and sustaining competition in the markets. Like most of the modern competition laws, the Act prohibits/ regulates three types of anti-competitive activities: a) Anti-competitive agreements (horizontal and vertical) (section 3); b) Abuse of dominant position (section 4); and c) Regulation of combinations (sections 5 and 6).

The Act recognizes the importance of IPRs, including the patents. While Section 3 of the Act prohibits anti-competitive agreements, sub-section (5) of Section 3 states that nothing contained in this section shall restrict "the right of any person to restrain any infringement of or to impose reasonable conditions, as may be necessary for protecting any of his rights, which have been or may be conferred upon him inter-alia under the Patents Act, 1970". The unreasonable conditions such as 'pay-for-delay' imposed by an originator, to protect his patent may, however, be anti-competitive under the Competition Act 2002. An unfair or discriminatory condition, when imposed by a dominant player, i.e., the originator, may also amount to an abuse of dominant position under Section 4 of the Competition Act, 2002. In the short run, a patent may create a monopoly in the form of exclusive rights. Still, in the long run, however, the IPR monopoly is not considered to conflict with the competition law, as the object of both is to promote innovation and competition.

\section{Competition Concerns in the Indian Pharmaceutical Industry}

Excessive regulation of the pharmaceutical sector has lessened the level of competition in the pharmaceutical markets. In the absence of fair competition, anti-competitive practices may be resorted to by market players who may deprive consumers as well as small producers of benefits of competitive markets. Some of the common anticompetitive practices in the pharmaceutical sector across the world as in India may be as follows:

Tie up between pharmaceutical companies and doctors: Pharmaceutical companies tend to endeavor to capture the market through inappropriate practices like entering into arrangements with doctors and their 
associations by providing various benefits to them. In pursuance to such arrangements, doctors prescribe costly medicines. Given the fact that decision making is in the hands of doctors \& pharmacists and not the consumer, such arrangements tend to influence availability, pricing, quality, and choice of drugs for the consumer. They may constitute vertical anticompetitive agreements and may be considered anticompetitive under section 3(4) of the Act.

Tie up Between Pharmaceutical Companies and Hospitals: Pharmaceutical companies tend to enter into arrangement or agreement with hospitals for the supply of drugs of their brand in their pharmacies alone and thereby to result in foreclosure of other companies from a supply of drugs with similar formulations to such hospitals which may be lower priced. Such an arrangement may increase the cost of treatment within the hospital, thereby reducing the accrual of benefits to the consumer. Such an arrangement may involve a violation in terms of section 3(4) (b) of the Act, i.e., exclusive supply agreement.

Tie up Between Pharmaceutical Companies and Retailers/Wholesalers: Pharmaceutical companies tend to enter into arrangements with retailers/wholesalers for the supply of drugs of their brand, which may result in the elimination of competing products and result in an increase in the cost of treatment. Such exclusive supply agreements violate section 3(4) (b) of the Act.

Collusion Amongst Pharmacists: Pharmacists tend to collude and enter into an arrangement to boycott a certain drug or drugs of a particular Pharmaceutical Company who give fewer margins to pharmacists. They may also collude to fix trade margins and various other restrictive practices that may adversely affect the availability and prices of drugs in retail markets. Such practices may be violated in section 3(3) and 3(4) of the Act.

Bid Rigging in Public Procurement: In developing countries like India, public procurement of pharmaceutical products is a very important activity of government. Bid rigging and collusion among suppliers of these products may artificially inflate the costs and adversely affect the efficiency of public spending and lower the benefits to the consumers. Bid rigging is prohibited under section 3(3) of the Act.
IPR Related Competition Issues: One of the essential requirements of competitive markets is the absence of entry barriers for the potential new comers. Most of the issues related to entry barriers in the pharmaceutical market are rooted in the patent law (or manipulating patent laws to prevent new entry in the market). Common anti-competitive practices affection ng competition inter -alia include patent ever-greening, pay for delay, and sham litigation.

\section{Competition Enforcement by the Competition Commission of India (CCI) \\ Anti-Competitive Practices in the Distribution of Pharmaceuticals}

Competition Commission of India has dealt with several cases involving anticompetitive practices prevailing in the distribution chain of the pharmaceutical sector and has found a violation of Section 3(3) and Section 3(4) of the Act by the trade associations of the chemists and druggists. Varca Druggist \& Chemist \&Ors v Chemists and Druggist Association, Goa, Santika Associates Pvt. Ltd. v All India Organization of Chemists and Druggist Associations were important cases on this issue. The primary allegations in these cases generally related to compulsory NOC from the trade association for appointing stockist, only members of the associations can be appointed as stockist or distributor, the limit of a number of the wholesaler in an area by the association, mandatory payment to the association in the name of Product Information Service (PIS), fixation of trade margins for stockists, fixation of discount, restrictions on bidding, a boycott of manufacturers, etc. The Competition Commission of India in most of these cases held that the said practices of the associations were anti-competitive and, therefore, ordered the respective associations to cease from engaging in such practices and also file an undertaking to the effect that such practices have been discontinued. The Commission also imposed penalties on associations. In some of the cases, the $\mathrm{CCI}$ also imposed on individual office bearers of the associations.

\section{Bid Rigging in Public Procurement}

Action against bid-rigging in public procurement is a key tool of competition enforcement, especially 
in developing countries where government spending accounts for a higher percentage of GDP. BioMed Private Limited v Union of India \& Others (Case No. 26 of 2013) case involves bid-rigging by Glaxo Smith Kline (GSK) Pharmaceuticals Limited, Mumbai, and Sanofi, Mumbai, two major global pharma players in a government tender for appropriation of QMMV - an anti-meningitis vaccine. Each year, the Government of India floats a tender for the purchase of QMMV for the purpose of preventing Indian pilgrims visiting Mecca on the 'Hajj' pilgrimage. There are only three principal players supplying QMMV vaccines in India - GSK, Sanofi, and Bio-Med (an Indian company). GSK is the largest supplier of this vaccine in the country. Based on investigations, CCI found that the conduct of GSK and Sanofi demonstrated that they were acting under an anti-competitive agreement. Both were held guilty of contravention of the provisions of section 3(3)(d) read with section 3(1) of the Act and levied a fine at the rate of $3 \%$ of their turnover mounting to INR 640 million approximately.

\section{Initiative taken the Government to Promote the} Pharmaceutical Sector in India is as Follows

- The Government of India plans to set up around eight mini drug-testing laboratories across major ports and airports in the country, which is expected to develop the drug administrative system and foundation facilities by monitoring the standards of imported and transported drugs and reduce the overall time spent on quality assessment.

- India is expected to rank among the top five global pharmaceutical discovery hubs by 2020 , based on Government of India's decision to allow 50 percent government funding in the pharmaceuticals sector through its Public-Private Partnership (PPP) model.

- Indian Pharmaceutical Association (IPA), the professional association of pharmaceutical companies in India, plans to prepare data uprightness guidelines, which will help to measure and benchmark the quality of Indian companies with global peers.

- The Government of India plans to incentivize bulk drug manufacturers, including both state- run and private companies, to encourage 'Make in India' program and reduce dependence on imports of Active Pharmaceutical Ingredients (API), nearly 85 percent of which come from China.

- The Department of Pharmaceuticals has set up an inter-ministerial co-ordination committee, which would periodically review, coordinate, and facilitate the interpretation of the issues and constraints faced by the Indian pharmaceutical companies.

- The Department of Pharmaceuticals has projected to originate a venture capital fund of Rs 1,000 crore (US\$ 149.11 million) to support start-ups in the investigation and improvement in the pharmaceutical and biotech industry.

\section{Conclusion}

Given the unique characteristics of the pharmaceutical sector (e.g., dealing with human lives, consumers being price takers, information asymmetry, low price elasticity, etc.), a relatively higher degree of regulation is necessary. However, higher regulation may often reduce competition in the market. Therefore, a fine balance is needed between the regulations and competition. Further, enforcement should not adversely affect the incentive to innovate in the sector so that consumers continue to benefit from new innovative products in the long run. On the one hand, a trade-off between regulations and competition is required; on the other hand, a balance between short-run excessive drug price and long-run innovation is also required. However, it is a separate debate as to what leads to innovation, whether competition in the market or incentive for higher profits through patent monopoly.

Note: Views expressed by the authors are personal and academic.

\section{References}

Bhattacharjea, Aditya and Fiyanshu Sindhwani. Competition Issues in the Indian Pharmaceuticals Sector, Delhi School of Economics, 2014.

Gulati, Archana G. Competition Issues in the Indian Pharmaceutical Sector, Competition Commission of India. 
Kale, Siddharth. Pharmaceutical Industry Sector in India, https://www.indianbarassociation.org/ pharmaceutical-industry-sector-in-india.

Mehta, Aashna et al. "A Critical Analysis of Concentration and Competition in the Indian Pharmaceutical Market." PLoS One, vol. 11, no. 2, 2016.

Mondal, S.S. and Viswanath Pingali. Competition Law and the Pharmaceutical Sector in India, Working Paper No. 2015-11-02, IIM Ahmedabad.

Mondal, S.S. and Viswanath Pingali. "Competition and Intellectual Property Policies in the Indian Pharmaceutical Sector." Vikalpa: The Journal for Decision Makers, vol 42, no. 2, 2017, pp. 61-79.

Nayak, Natasha. Competition Impediments in the Pharmaceutical Sector in India, https:/iica.nic.in/images/sclmr research/ Pharmaceuticals\%20Sector.pdf.

Reddy, A.V.J. and B.M. Rao. "Opportunities and Challenges for Indian Pharmaceutical Companies in Overseas Markets and need of Digital tools for Sustainable Success." Indian Journal of Pharmaceutical Education and Research, vol. 51, no. 2, 2017, pp. 226-238.

Tannoury, Maya and Zouhair Attieh. "The Influence of Emerging Markets on the Pharmaceutical Industry." Current Therapeutic Research, vol. 86, 2017, pp. 19-22.

The Indian Pharmaceutical Industry - The Way Forward, Innovation, Quality and Reach, 2019, https:/www.ipa-india.org/static-files/ pdf/publications/position-papers/2019/ipaway-forward.pdf.

\section{Author Details}

Dr. M. Chitra, Assistant Professor, Department of Econometrics, Madurai Kamaraj University, Madurai, Tamil Nadu, India, Email ID: Chitra.eco@mkuniversity.org

Nandan Kumar, Joint Director (Economics), Competition Commission of India, New Delhi, India 